\title{
Molecular screening of ovine mastitis in different breeds
}

\author{
O. Guerreiro, ${ }^{*} \dagger$ Z. Velez, ${ }^{*}{ }^{1}$ N. Alvarenga, $\ddagger$ C. Matos, $\S$ and M. Duarte ${ }^{*} \dagger^{2}$ \\ *Centro de Biotecnologia Agrícola e Agro-Alimentar do Baixo Alentejo e Litoral (CEBAL), Instituto Politécnico de Beja (IPBeja), \\ 7801-908 Beja, Portugal \\ †Centre for Research in Ceramics \& Composite Materials (CICECO), University of Aveiro, 3810-193 Aveiro, Portugal \\ ‡Departamento Tecnologia e Ciências Aplicadas, Escola Superior Agrária, IPBeja, 7801-908 Beja, Portugal \\ §Associação de Criadores de Ovinos do Sul (ACOS), 7801-904 Beja, Portugal
}

\section{ABSTRACT}

Clinical and subclinical mastitis directly affect mammary gland function and have a great economic impact on the sheep and goat dairy industries. The present study explores molecular diagnosis of ovine subclinical mastitis as a faster and more precise screening method compared with microbiology and biochemical techniques to assess the molecular and chemical properties of raw milk samples from healthy animals from 3 breeds of sheep raised in Portugal. Based on 16S ribosomal RNA screening by PCR, milk samples from all sheep were categorized as contaminated $(\mathrm{n}=123)$ or noncontaminated $(\mathrm{n}=104)$. For contaminated milk, different specific primers were used for pathogen identification (Staphylococcus aureus, Streptococcus agalactiae, Streptococcus dysgalactiae, and Streptococcus uberis). Streptococcus agalactiae was identified as the most frequent agent. We further assessed whether contaminated versus noncontaminated samples were chemically different in terms of fat, protein, lactose, $\mathrm{pH}$, and solids-not-fat. This molecular screening method allowed rapid and efficient identification of contaminated raw sheep milk, including pathogen identification, before significant alterations in milk chemical properties could be detected. This methodology may lead to a specific and efficient animal treatment and consequently less expensive flock management.

Key words: subclinical mastitis, sheep milk, DNA extraction, PCR-based screening method

\section{INTRODUCTION}

In southeastern Portugal, raw sheep milk from different local and exotic breeds is traditionally transformed into cheese. Serpa, a Protected Denomination of Origin

\footnotetext{
Received March 9, 2012.

Accepted October 23, 2012.

${ }^{1}$ Current address: Centro de Ciências do Mar (CCMAR), Universidade do Algarve, Campus de Gambelas, 8005-139 Faro, Portugal.

${ }^{2}$ Corresponding author: fatima.duarte@cebal.pt
}

cheese by European Union regulations, is a traditional Portuguese cheese with a unique strong aroma and spicy flavor (Alvarenga et al., 2008). The maintenance of milk quality depends greatly on flock health; several livestock diseases may alter milk properties, thus affecting final cheese quality. One of the most common dairy sheep health problems is mastitis - infection and inflammation of the udder that directly affects mammary gland function (Meiri-Bendek et al., 2002; Al-Majali and Jawabreh, 2003). As raw sheep milk is solely used for cheese production, late detection of mastitis may have a negative effect, not only on productivity, but also on final cheese quality, and thus having a negative economic effect. Furthermore, early identification of contaminants in dairy herds might help in formulating efficient strategies to reduce mastitis prevalence. Therefore, assessment and rapid diagnosis of ovine mastitis, with precise pathogen identification, is of great importance.

Mastitis may result from trauma, udder injury, chemical irritation, or bacterial infection, and it is classified into 2 major types: clinical and subclinical (Al-Majali and Jawabreh, 2003; Cremonesi et al., 2006). Clinical mastitis is characterized by presentation of visible signs, and is generally associated with alterations in milk composition, such as increased $\mathrm{pH}$ and milk SCC and decreased lactose and total fat contents, leading to a reduction in milk yield and quality (Ogola et al., 2007; Raynal-Ljutovac et al., 2007). Subclinical cases, characterized by the absence of visible signs, are more persistent and highly contagious to the rest of the flock, because animals are asymptomatic (which can lead to late or no diagnosis) while in contact with healthy animals (Al-Majali and Jawabreh, 2003; Viguier et al., 2009). According to Bergonier et al. (2003), the incidence of sheep clinical mastitis is generally less than $5 \%$, whereas that of subclinical cases ranges from 16 to $35 \%$; thus, the overall disease burden is likely to be underestimated, with a huge economic impact on flock management (Leitner et al., 2004) and animal health.

A wide range of infectious microorganisms is known to cause mastitis, generally being classified by reser- 
voir and mode of transmission. Contagious pathogens (the major agents causing subclinical mastitis) such as Staphylococcus aureus and Streptococcus agalactiae are transmitted among animals by direct contact with infected milk; for example, on animal beds or during the milking process (Al-Majali and Jawabreh, 2003; Mørk et al., 2007). Environmental pathogens such as Streptococcus uberis and Streptococcus dysgalactiae are generally opportunistic invaders of the mammary gland (Riffon et al., 2001; Cremonesi et al., 2006; Mørk et al., 2007), although Strep. dysgalactiae may also present contagious characteristics, spreading from animal to animal (Bradley, 2002).

Different diagnostic methods have been developed to assess contamination status as well as detection and identification of mammary gland pathogens (Riffon et al., 2001; Meiri-Bendek et al., 2002; Cremonesi et al., 2006). According to the National Mastitis Council (1998) standards, currently available microbiology and biochemical techniques for screening and identification of raw milk pathogens requires at least $48 \mathrm{~h}$ until the confirmed results. In addition, many of the commercially available microbiological identification systems (such as API20, bioMérieux Inc., Hazelwood, MO) cannot identify, in ovine milk, many of the most relevant mastitis pathogens, such as Strep. agalactiae, Strep. dysgalactiae, and Strep. uberis (Riffon et al., 2001; Viguier et al., 2009).

Because of the limitations of diagnostic tools based on microbiology, the development of molecular biology techniques provides a promising option for rapid animal screening, allowing discrimination between closely related contamination organisms. Raw bovine and ovine milk samples could serve as templates for amplification of specific DNA sequences using PCR (Lipkin et al., 1993; Berri et al., 2000). Moreover, species-specific DNA sequences such as the intergenic conserved ribosomal (r)RNA genes (16S or 23S rRNA), or even the entire intergenic spacer region (16S-23S rRNA) of the ribosomal RNA operon, can be used for a rapid (hours) identification of contaminated samples, rather than days, as in microbiology methods (Riffon et al., 2001; Meiri-Bendek et al., 2002; Cremonesi et al., 2006). Several studies on bovine mastitis screening have demonstrated the advantages of molecular biologybased methods compared with traditional microbiology techniques (Riffon et al., 2001; Cremonesi et al., 2006): less time consumed and the ability to identify a wider range of contamination agents were highlighted. Studies describing application of molecular tools for ovine mastitis diagnosis are scarce (López-Calleja et al., 2004; Mafra et al., 2004). Moreover, the studies undertaken did not standardize an ovine raw milk DNA extraction protocol, a significant drawback in the context of routine molecular biology-based procedures. Molecular tools designed for bovine mastitis diagnosis are considerably more developed, with optimized DNA extraction and pathogen identification by PCR-based methods (Riffon et al., 2001; Cremonesi et al., 2006). Currently, efficient and rapid bovine mastitis screening tests have been developed that allow the combination of certain milk properties with molecular biology assays (Riffon et al., 2001).

The present work addresses the molecular diagnosis of ovine subclinical mastitis, assessing the molecular and chemical properties of raw milk samples from different sheep breeds. To the best of our knowledge, this is the first report on screening for ovine subclinical mastitis diagnosis using DNA extraction and PCRbased methods, where 4 different pathogens are tested (Staph. aureus, Strep. agalactiae, Strep. dysgalactiae, and Strep. uberis).

\section{MATERIALS AND METHODS}

\section{Animals and Samples}

The animals used in this study were of 3 different breeds raised in southern Portugal. Merino and Campaniça are local breeds raised under extensive conditions. Today, they are mainly used for meat production, but in the past, milk from these breeds was transformed into high-quality cheese. Today, the Lacaune, of French origin, is the main dairy sheep breed used in the region for cheese production; Lacaune sheep are raised in semi-intensive conditions.

In total, 227 milk samples from the 3 sheep breeds were randomly collected (Table 1) from different flocks in the Baixo Alentejo region of southeastern Portugal. For the Lacaune breed, milk samples were collected in 3 stages of lactation: early, mid, and late lactation. All Campaniça and Merino milk samples were collected in late lactation.

For the purpose of this study, milk samples were collected manually from ewes without visible signs of mastitis just before the afternoon milking. The first streams of each individual milk collection were discarded, and then $25 \mathrm{~mL}$ from each half udder (a total of $50 \mathrm{~mL}$ ) was pooled in the same sterile tube and transported to the laboratory in isothermal boxes $\left(4^{\circ} \mathrm{C}\right)$.

\section{DNA Extraction}

A raw ovine milk sample (control) was used to test 6 different DNA extraction protocols, protocols I to VI. Protocols I (Cremonesi et al., 2006), II (López-Calleja et al., 2004), III (Murphy et al., 2002), and V (Miller et al., 1988) were performed according to the published 
Table 1. Data distribution: number of samples by breed, producer, and stage of lactation

\begin{tabular}{lclc}
\hline Breed & Producer & $\begin{array}{l}\text { Stage of } \\
\text { lactation }\end{array}$ & $\begin{array}{c}\text { Number of } \\
\text { samples }\end{array}$ \\
\hline Lacaune & 1 & Late & 63 \\
& 2 & Early & 78 \\
& & Mid & 33 \\
Campaniça & 3 & Late & 17 \\
Merino & 4 & Late & 21 \\
Total milk samples & & Late & 15 \\
\hline
\end{tabular}

descriptions, with minor modifications. Protocols IV and VI were done according to the manufacturer's instructions using commercially available kits: EZNA Tissue DNA Isolation Kit (Omega Bio-Tek, Norcross, GA) and NucleoSpin Tissue Kit (Macherey-Nagel, Düren, Germany), respectively. After optimization (testing all 6 protocols and finding protocol $\mathrm{V}$ to be the best for DNA extraction), protocol $\mathrm{V}$ was selected to perform all milk DNA extractions using a step to remove the fat residue and isolate the somatic cell pellet, followed by salting out of cellular proteins by dehydration and precipitation with a saturated $\mathrm{NaCl}$ solution.

Briefly, DNA extraction was carried out starting with $5 \mathrm{~mL}$ of raw ovine milk diluted in $10 \mathrm{~mL}$ of PBS $(\mathrm{pH}$ 7.4) followed by 2 centrifugations at $1,036 \times g$ for 10 min each at $4^{\circ} \mathrm{C}$ to remove the milk fat residue, including cream pad. The isolated somatic cell pellet was suspended in $200 \mu \mathrm{L}$ of cold PBS, and the cells were lysed at room temperature $\left(\mathrm{RT} ; 25^{\circ} \mathrm{C}\right)$ for $1 \mathrm{~h}$ in $3 \mathrm{~mL}$ of nucleic lysis buffer $[10 \mathrm{~m} M$ Tris- $\mathrm{HCl}$ (Merck KGaA, Darmstadt, Germany), $400 \mathrm{~m} M \mathrm{NaCl}$ (Merck KGaA), and $2 \mathrm{mM} \mathrm{Na} \mathrm{NDDTA}_{2}$ (BDH Prolabo, Lutterworth, UK) at $\mathrm{pH}$ 8.2]. The cell lysate was further digested overnight at $37^{\circ} \mathrm{C}$ with $200 \mu \mathrm{L}$ of $10 \%$ SDS (Promega, Madison, $\mathrm{WI}$ ), $500 \mu \mathrm{L}$ of protease $\mathrm{K}$ solution (1 $\mathrm{mg}$ of proteinase $\mathrm{K}$ in $1 \%$ SDS and $2 \mathrm{mM} \mathrm{Na} 2$ EDTA; 5 Prime Inc., Gaithersburg, MD). After digestion, $1 \mathrm{~mL}$ of saturated $\mathrm{NaCl}(6 M)$ was added and the mixture centrifuged at $720 \times g$ for $15 \mathrm{~min}$ at $20^{\circ} \mathrm{C}$. The supernatant containing the DNA was transferred and precipitated at $25^{\circ} \mathrm{C}$ with 2 volumes of absolute ethanol. The DNA pellet was then dissolved in $100 \mu \mathrm{L}$ of Tris-EDTA buffer $(10 \mathrm{mM}$ Tris- $\left.\mathrm{HCl}, 0.2 \mathrm{mM} \mathrm{Na} \mathrm{NDDT}_{2} \mathrm{pH} 7.5\right)$ for $2 \mathrm{~h}$ at $37^{\circ} \mathrm{C}$. The quantity and quality of DNA samples were measured using a NanoVue Plus spectrophotometer (GE Healthcare Ltd., Fairfield, CT).

\section{PCR Reactions and Product Detection}

Genes encoding rRNA, rather than genes encoding mRNA, were used as target sequences because of the presence of several gene copies encoding rRNA in the genome (Bentley and Leigh, 1995).
All reactions were carried out in a Thermal Cycler MyCycler (Bio-Rad Laboratories, Hercules, CA), in a final volume of $25 \mu \mathrm{L}$, containing 10 to $50 \mathrm{ng} / \mu \mathrm{L}$ of template DNA, $200 \mu M$ concentration of each dNTP (Fermentas Inc., Glen Burnie, MD), 1.5 to $2 \mathrm{mM}$ $\mathrm{MgCl}_{2}$ (Fermentas Inc.), 0.3 to $1.25 \mu \mathrm{M}$ concentration of each forward and reverse primer (Thermo Scientific, Waltham, MA), and 0.5 to $1.25 \mathrm{U}$ of DNA polymerase (Fermentas Inc.), depending on the amplified gene, in reaction buffer (Dream Taq buffer, Fermentas Inc.).

Primer sequences, annealing temperatures, cycle numbers, and size of the amplicon for the different primer settings are reported in Table 2. Positive and negative controls were included in each $\mathrm{PCR}$ reaction to verify PCR efficiency and detection of contaminated samples. For $\kappa$-casein and cytochrome b genes and PCR products for the $16 \mathrm{~S}$ gene, $5 \mu \mathrm{L}$ of the PCR product was mixed with $2 \mu \mathrm{L}$ of gel loading dye (Fermentas Inc.) and analyzed by electrophoresis on $2,1.5$, and $1 \%$ agarose gels (Lonza, Allendale, NJ), respectively, under the same conditions. The molecular size marker, a 100bp ladder (Fermentas Inc.), was run concurrently. All PCR products were then visualized and photographed by UV transillumination (Gel-Doc XR System, BioRad Laboratories).

\section{Ovine Milk Chemical Analysis}

All raw milks were analyzed for fat, protein, lactose, and SNF contents using a Milkoscan FT 6000 (Foss Electric, Hillerød, Denmark), and SCC was determined on a Fossomatic FC (Foss Electric). The $\mathrm{pH}$ was measured using the C861 Benchtop electrochemistry meter model (Consort, Turnhout, Belgium).

\section{Statistical Analyses}

All data were analyzed using SAS software (2004; SAS Institute Inc., Cary, NC). For contaminated milk, the hypothesis of association between breed and pathogen agent ( 3 breeds $\times 4$ pathogen contingency; Table 3 ) was evaluated by $\chi^{2}$ test (PROC FREQ of SAS). Variation in milk composition parameters from Lacaune breed 
caused by stage of lactation, contamination status, and their interaction was tested using PROC GLM. Using milk composition data from all breeds within the same lactation stage, breed effect, contamination status, and their interaction were also tested using PROC GLM.

\section{RESULTS}

Six genomic DNA extraction protocols were tested, using the same raw milk control sample, to identify the most efficient protocol in terms of DNA quantity and quality (Dotti, 2011). The genomic DNA profiles obtained using all extraction methods are presented in the supplementary data (Supplementary Figure S1, available online at http://www.journalofdairyscience. org/). According to the results, DNA from protocols I, II, and III had lower purity and was contaminated with protein, phenolate ions, thiocyanates, and other organic compounds, based on 260:280 and 260:230 absorbance ratios (Table 4). Protocols IV, V, and VI resulted in better DNA quality, in terms of final DNA concentration (Table 4) and DNA integrity (Supplementary Figure S1, available online at http://www.journalofdairyscience.org/). The concentration of DNA obtained with protocol IV was considerably lower than that obtained with protocols $\mathrm{V}$ and VI, probably because of an inefficient final elution step (Table 4). Thus, DNA obtained from protocols $\mathrm{V}$ and VI yielded the greatest quantities of DNA, with slight differences in final concentrations (220 vs. $302 \mathrm{ng} / \mu \mathrm{L}$ ), and 260:280 ratios ranging between 1.7 and 1.8, indicative of a good deproteinization step (Table 4). Based on final DNA concentrations and ratio values (with both procedures having similar results), the final procedure cost (less for noncommercial kits), and no requirement to use a specific commercial

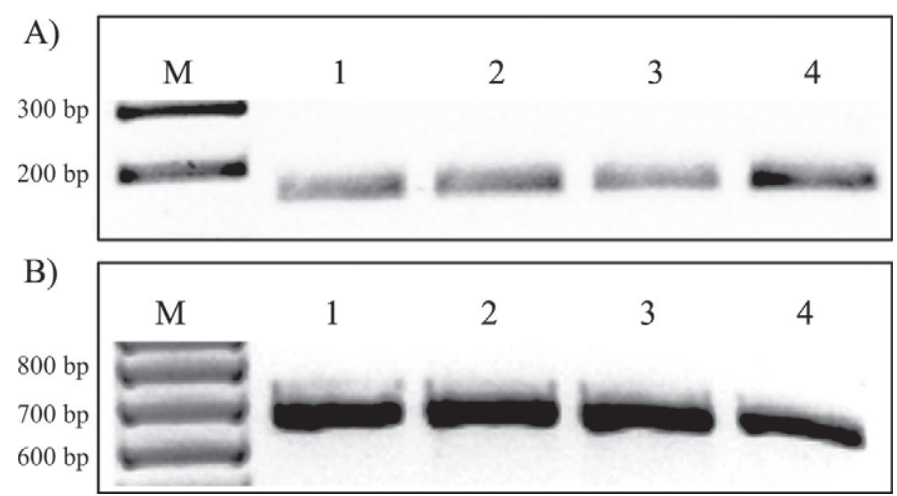

Figure 1. Agarose gel electrophoresis of PCR products amplified for the 2 reference genes in study: (A) $\kappa$-casein gene (164 bp) and (B) cytochrome b gene $(660 \mathrm{bp}) . \mathrm{M}=100$-bp ladder (Fermentas Inc., Glen Burnie, MD); lanes 1 to $4=$ positive samples (samples that amplified for these 2 genes). 
Table 3. Breed by pathogen agent contingency table (number of samples)

\begin{tabular}{lccc}
\hline Pathogen & Lacaune & Campaniça & Merino \\
\hline Streptococcus agalactiae & 54 & 3 & 4 \\
Staphylococcus aureus & 19 & 6 & 3 \\
Streptococcus dysgalactiae & 33 & 7 & 9 \\
Streptococcus uberis & 8 & 1 & 0 \\
\hline
\end{tabular}

kit, protocol $\mathrm{V}$ was the preferred one. The specificity of protocol V was further tested by extracting DNA from raw sheep, goat, and cow milk samples (Supplementary Figure S2, available online at http://www.journal ofdairyscience.org/). Based on these results, protocol $\mathrm{V}$ extracted DNA of similar quality from sheep and goat milks, whereas the protocol was less efficient for cow milk (Supplementary Table S1, available online at http://www.journalofdairyscience.org).

Protocol V was thus used in all ovine raw milks ( $\mathrm{n}=$ 227), and all DNA quantities and quality were comparable to the initial control sample. After extraction, all DNA samples were successfully amplified for $\kappa$-casein and cytochrome b genes (Figure 1). The DNA extraction method generated amplifiable products of 164 and $660 \mathrm{bp}$ for $\kappa$-casein and cytochrome $\mathrm{b}$, respectively (Figure 1A and 1B), for all samples, without the need for additional enrichment or further purification. The detection of contaminated milk samples was further assessed by using a $16 \mathrm{~S}$ rRNA PCR (Figure 2). From a total of 227 milk samples collected from animals without any clinical sign of mastitis, $16 \mathrm{~S}$ rRNA PCR products (i.e., indicating contaminated samples) were obtained in 123 cases (54\% of total). The remaining 104 DNA samples could not be amplified by the $16 \mathrm{~S}$ oligonucleotides, indicating a noncontaminated status for those samples. As expected, amplification was not observed in PCR negative controls. The contaminated ovine milk samples were mostly of the Lacaune breed ( $42 \%$ of total milk samples), followed by Campaniça $(8 \%)$ and Merino (4\%) breeds. Four pathogens were detected, with Strep. agalactiae being the most frequent (32\%), followed by Strep. dysgalactiae (29\%), Staph. aureus (18\%), and Strep. uberis (5\%; Figure 3). The remaining samples $(16 \%)$ were those DNA positive for $16 \mathrm{~S}$ rRNA; that is, not contaminated by any of the 4

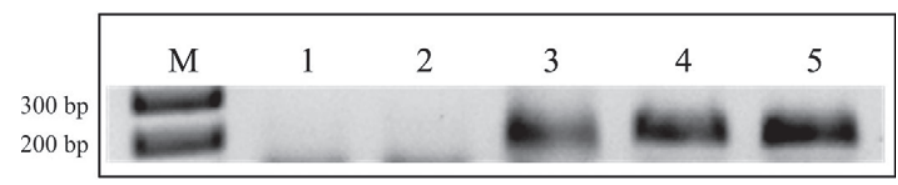

Figure 2. Agarose gel electrophoresis of PCR products amplified for 16S rRNA (210 bp). M = 100-bp ladder (Fermentas Inc., Glen Burnie, MD); lane $1=$ negative control; lane $2=$ noncontaminated sample; and lanes 3 to $5=$ contaminated samples. pathogens under study. The positivity of $16 \mathrm{~S}$ rRNA PCR for those samples indicates that they were contaminated either with other pathogens responsible for ovine mastitis or with any other nonpathogenic bacteria present in milk; they were not further considered in subsequent statistical analyses. The $\chi^{2}$ analysis showed no association between breed and pathogen $(P>0.05$; Table 3).

We next compared contaminated and noncontaminated samples, assessing their chemical composition at 3 stages of lactation to determine whether contaminated samples revealed a different composition profile from noncontaminated samples. For the Lacaune breed, stage of lactation, contamination status, and their interaction had a significant $(P<0.05)$ effect on milk chemical constituents other than fat content (Table $5)$. Contamination status was significant for lactose content, SCC, and $\mathrm{pH}$, whereas the interaction between stage of lactation and contamination status was significant only for protein, lactose content, and milk $\mathrm{pH}$ (Table 5). When comparing contaminated and noncontaminated milk samples, significant differences were not detected for fat, SNF, or SCC contents. Protein levels remained unchanged for contaminated samples from mid to late lactation $(5.41 \pm 0.25$ to $5.90 \pm 0.28$ $\mathrm{g} / 100 \mathrm{~mL}$ ); however, within early lactation, contaminated milk samples had higher protein content $(P<$ $0.05)$ than noncontaminated samples $(6.77 \pm 0.48$ and $5.27 \pm 0.29 \mathrm{~g} / 100 \mathrm{~mL}$, respectively; Table 6).

Table 4. Ratio values (absorbance ratios at 260:280 nm and at 260:230 $\mathrm{nm}$ ) and DNA concentration according to the 6 different protocols, using the raw ovine milk sample as the control

\begin{tabular}{lccc}
\hline Protocol $^{1}$ & $\mathrm{Abs}_{260 / 280}$ & $\mathrm{Abs}_{260 / 230}$ & $\begin{array}{c}\text { Concentration } \\
(\mathrm{ng} / \mu \mathrm{L})\end{array}$ \\
\hline I & 1.4 & 0.07 & 10.7 \\
II & 0.7 & 0.1 & 700 \\
III & 1.1 & 0.2 & 475 \\
IV & 1.8 & 1.3 & 66.5 \\
V & 1.7 & 1.2 & 220 \\
VI & 1.7 & 2.0 & 302 \\
\hline
\end{tabular}

${ }^{1}$ Protocol I = Cremonesi et al. (2006); protocol II = López-Calleja et al. (2004); protocol III = Murphy et al. (2002); protocol IV = EZNA Tissue DNA Isolation Kit (Omega Bio-Tek, Norcross, GA); protocol $\mathrm{V}=$ Miller et al. (1988); and protocol VI = NucleoSpin Tissue Kit (Macherey-Nagel, Düren, Germany). 

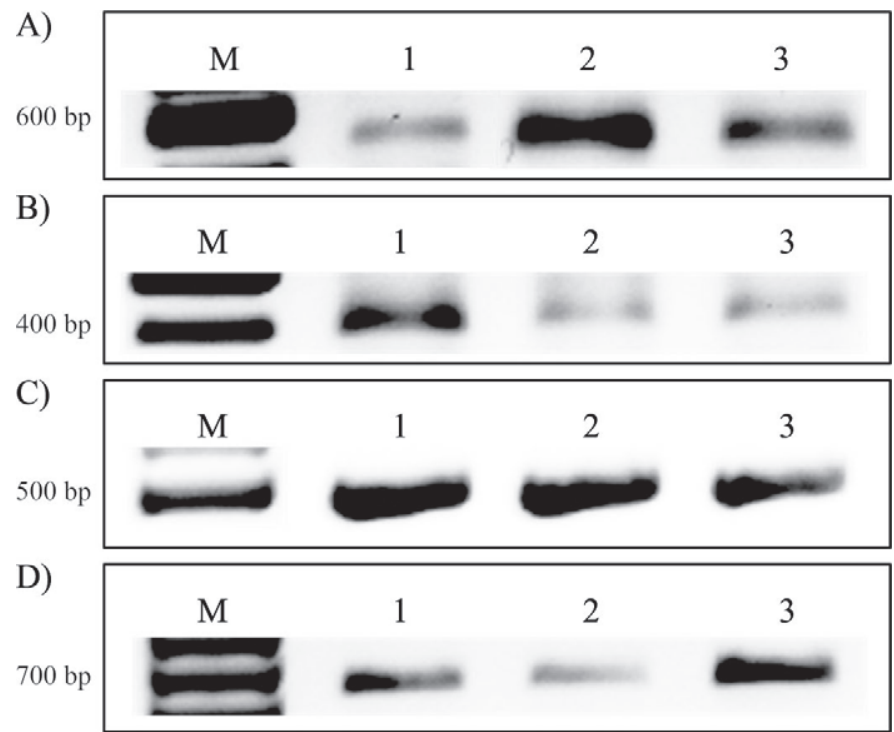

Figure 3. Detection of major pathogens by PCR: (A) Streptococcus agalactiae (586 bp), (B) Streptococcus dysgalactiae (401 bp), (C) Staphylococcus aureus (499 bp), and (D) Streptococcus uberis (624 bp). $\mathrm{M}=100$-bp ladder (Fermentas Inc., Glen Burnie, MD); lanes 1 to $3=$ contaminated samples for one of the pathogens.

Regarding lactose content, contaminated milk samples had lower lactose levels $(1.52 \pm 0.47 \mathrm{~g} / 100 \mathrm{~mL})$ in early lactation than noncontaminated samples $(4.00$ $\pm 0.29 \mathrm{~g} / 100 \mathrm{~mL}$; Table 6$). \mathrm{pH}$ values decreased with advancing lactation $(P<0.05)$, and noncontaminated samples had lower $\mathrm{pH}(P<0.0001)$ compared with contaminated samples in early lactation (when $\mathrm{pH}$ levels were highest). In late lactation, contaminated samples had higher $\mathrm{pH}(7.00 \pm 0.07)$ than noncontaminated samples $(6.68 \pm 0.07 ; P<0.05)$.

We further compared the 3 breeds in late lactation because Merino and Campaniça are traditionally milked after a suckling period of approximately 3 mo. Therefore, to obtain a fair comparison among breeds, only samples taken in late lactation were used (Tables 7 and 8). No significant differences were detected regarding fat, protein, and lactose contents.
Noncontaminated Merino milk samples had higher SNF levels $(13.10 \pm 0.38 \mathrm{~g} / 100 \mathrm{~mL})$ compared with those from Lacaune and Campaniça (12.27 \pm 0.30 and $10.83 \pm 0.59 \mathrm{~g} / 100 \mathrm{~mL}$, respectively). In the Lacaune breed, SNF content was lower in the contaminated samples $(10.94 \pm 0.28 \mathrm{~g} / 100 \mathrm{~mL})$ than in the noncontaminated samples $(12.27 \pm 0.30 \mathrm{~g} / 100 \mathrm{~mL} ; P<$ $0.05)$, whereas no significant differences were detected in contaminated versus noncontaminated samples of Campaniça and Merino. Contaminated samples from Lacaune had the highest $\mathrm{pH}$ values regardless of the breed or the contamination status $(7.00 \pm 0.04 ; P<$ 0.05). No differences were detected in contaminated versus noncontaminated samples in Campaniça and Merino breeds.

\section{DISCUSSION}

Mastitis is an infection and inflammation of the udder affecting mammary gland function, causing alterations in milk chemical properties and cheese yield and quality. So far, sensitive, rapid, and specific tests to identify the main pathogens, which cause heavy losses in sheep dairy industry, are not yet available.

In the current study, we developed a molecular-based diagnostic tool for identification of sheep with contaminated milk as an indicator for subclinical mastitis. Molecular approaches to diagnosis have many advantages. Numerous studies using PCR toward the 16S rRNA gene sequence have allowed detection of many bacteria from different sources (Riffon et al., 2001). Moreover, highly specific oligonucleotides probes can be used to identify individual bacteria species in a broad range of biological samples, including milk (Lipkin et al., 1993).

Few studies regarding the incidence of subclinical mastitis in Lacaune dairy ewes are available (Al-Majali and Jawabreh, 2003; Bergonier et al., 2003). According to the current study, the overall percentage of contaminated milk samples derived from Lacaune dairy ewes was considerably higher than previously described by Barillet et al. (2001), who reported a prevalence of clinical mastitis of $10.4 \%$ based on SCC in the Roque-

Table 5. Source of variation, degrees of freedom, coefficients of determination $\left(\mathrm{R}^{2}\right)$, and $\mathrm{CV}$ for different milk composition parameters for the Lacaune breed

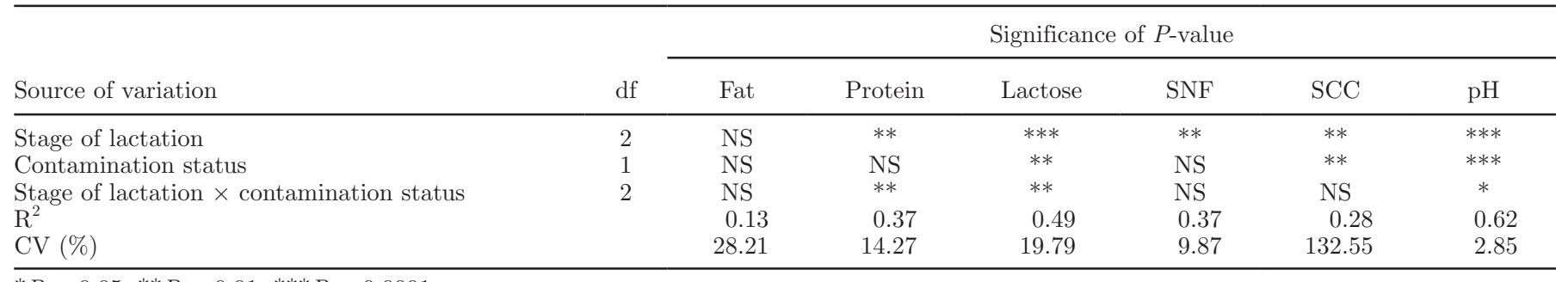

${ }^{*} P<0.05 ;{ }^{* *} P<0.01 ;{ }^{* * *} P<0.0001$. 
Table 6. Estimated least squares means for different milk composition parameters by stage of lactation and contamination status for the Lacaune breed

\begin{tabular}{|c|c|c|c|c|c|c|c|c|}
\hline $\begin{array}{l}\text { Stage of } \\
\text { lactation }\end{array}$ & Status $^{1}$ & $\begin{array}{l}\text { Samples } \\
\text { (proportion, \%) }\end{array}$ & $\begin{array}{c}\text { Fat } \\
(\mathrm{g} / 100 \mathrm{~mL})\end{array}$ & $\begin{array}{l}\text { Protein } \\
(\mathrm{g} / 100 \mathrm{~mL})\end{array}$ & $\begin{array}{c}\text { Lactose } \\
(\mathrm{g} / 100 \mathrm{~mL})\end{array}$ & $\begin{array}{c}\text { SNF } \\
(\mathrm{g} / 100 \mathrm{~mL})\end{array}$ & $\begin{array}{c}\mathrm{SCC} \\
\left(\times 10^{3} \text { cells } / \mathrm{mL}\right)\end{array}$ & $\mathrm{pH}$ \\
\hline \multirow[t]{2}{*}{ Early } & CONT & $\mathrm{n}=16(50)$ & $8.27 \pm 1.35$ & $6.77 \pm 0.48^{\mathrm{a}}$ & $1.52 \pm 0.47^{\mathrm{b}}$ & $9.59 \pm 0.62$ & $9,714 \pm 2,245$ & $7.66 \pm 0.11^{\mathrm{a}}$ \\
\hline & $\mathrm{NCT}$ & $\mathrm{n}=16(50)$ & $6.76 \pm 0.83$ & $5.27 \pm 0.29^{\mathrm{b}}$ & $4.00 \pm 0.29^{\mathrm{a}}$ & $10.17 \pm 0.38$ & $3,799 \pm 1,374$ & $7.03 \pm 0.07^{\mathrm{b}}$ \\
\hline Mid & NCT & $\mathrm{n}=12(36.36)$ & $8.81 \pm 1.04$ & $5.24 \pm 0.37^{\mathrm{b}}$ & $4.67 \pm 0.36^{\mathrm{a}}$ & $10.68 \pm 0.48$ & $754 \pm 1.739$ & $6.73 \pm 0.09^{\mathrm{cd}}$ \\
\hline \multirow[t]{2}{*}{ Late } & CONT & $\mathrm{n}=55(63.22)$ & $8.13 \pm 0.78$ & $5.90 \pm 0.28^{\mathrm{ab}}$ & $4.13 \pm 0.27^{\mathrm{a}}$ & $10.94 \pm 0.36$ & $3,639 \pm 1,296$ & $7.00 \pm 0.07^{\mathrm{b}}$ \\
\hline & NCT & $\mathrm{n}=32(36.78)$ & $9.52 \pm 0.83$ & $6.71 \pm 0.29^{\mathrm{a}}$ & $4.58 \pm 0.29^{\mathrm{a}}$ & $12.27 \pm 0.38$ & $506 \pm 1.375$ & $6.68 \pm 0.07^{\mathrm{d}}$ \\
\hline
\end{tabular}

${ }^{\mathrm{a}-\mathrm{d}}$ Means within a column with different superscripts differ $(P<0.05)$.

${ }^{1}$ Contamination status: $\mathrm{CONT}=$ contaminated; $\mathrm{NCT}=$ noncontaminated.

fort region of France. A recent evaluation of IMI using bacteriological analyses and measurement of SCC in Sarda dairy sheep demonstrated a prevalence of $41.9 \%$ (Cuccuru et al., 2011). Our results indicate a high prevalence of subclinical mastitis - a total incidence of $54 \%$, considerably higher than previously estimated by Bergonier et al. (2003).

The major pathogen identified, Strep. agalactiae, is a contagious pathogen (Riffon et al., 2001; Cremonesi et al., 2006; Mørk et al., 2007) frequently associated with mastitis, as is Staph. aureus. The main reservoir of both agents is the mammary gland; however, these bacteria can survive and grow outside the mammary gland, be spread from animal to animal, and further transmitted to uninfected animals during milking (Meiri-Bendek et al., 2002; McDonald et al., 2005). Their early detection is thus crucial. Methods based on PCR reveal higher percentages of contaminated samples; for example, we identified that $32 \%$ of contaminated samples were contaminated with Strep. agalactiae, whereas Lafi et al. (1998), using bacteriological culture and SCC, reported an incidence of IMI caused by Strep. agalactiae of $6.8 \%$ in Awassi dairy sheep. For Strep. dysgalactiae, we identified $29 \%$ PCR-positive samples, whereas Cuccuru et al. (2011) detected $10.4 \%$ in Sarda sheep by bacteriological culture.

Numerous studies have suggested a direct correlation between mastitis and milk composition, such as decreases in fat, total protein, lactose, and SNF contents
(Raynal-Ljutovac et al., 2007). Stage of lactation and animal breed are also known to have an overall effect on milk composition (Abilleira et al., 2010; Leitner et al., 2011). Abilleira et al. (2010) observed that protein content increases with advancing lactation, whereas others have described the opposite (Sevi et al., 2004). Some authors observed increased protein content in milk samples with elevated SCC (Albenzio et al., 2004; Bianchi et al., 2004); however, Leitner et al. (2011) did not find differences in protein content between contaminated and noncontaminated samples, even in high SCC milk samples. These discrepancies may be attributed to several factors involved in changes occurring in protein content with advanced lactation and contamination status, such as a reduction in secreted milk volume, enhanced influx of protein serum from the extracellular fluid into milk, and leukocyte recruitment, which can cause extensive epithelium secretory cell damage (Sevi et al., 2001).

In subclinical mastitis, lactose synthesis tends to decrease and lactose is partially substituted by other factors, such as chlorides (Sevi et al., 2004). According to the same study, lactose content in healthy animals remains substantially unchanged during lactation (Sevi et al., 2004). However, our results indicate a constant lactose level in mid and late lactation, regardless of contamination status. Our $\mathrm{pH}$ results are in agreement with previous reports (Bianchi et al., 2004; RaynalLjutovac et al., 2007).

Table 7. Source of variation, degrees of freedom, coefficients of determination $\left(\mathrm{R}^{2}\right)$, and $\mathrm{CV}$ for different milk composition parameters in Lacaune, Campaniça, and Merino breeds

\begin{tabular}{lcccccc}
\hline & \multicolumn{5}{c}{ Significance of $P$-value } \\
\cline { 3 - 7 } Source of variation & df & Fat & Protein & Lactose & SNF & pH \\
\hline Breed & 2 & $* *$ & $* * *$ & NS & $* * *$ & $* *$ \\
Contamination status & 1 & NS & NS & NS & NS & $* *$ \\
Breed $\times$ contamination status & 2 & NS & NS & NS & NS & $*$ \\
$\mathrm{R}^{2}$ & & 0.36 & 0.54 & 0.13 & 0.45 & 0.52 \\
CV $(\%)$ & & 16.87 & 11.17 & 11.90 & 7.11 & 1.99 \\
\hline
\end{tabular}

${ }^{*} P<0.05 ;{ }^{* *} P<0.01 ;{ }^{* * *} P<0.0001$. 
Table 8. Estimated least squares means for different milk composition parameters by stage of lactation and contamination status for the Lacaune, Campaniça, and Merino breeds

\begin{tabular}{|c|c|c|c|c|c|c|}
\hline Breed & Status $^{1}$ & $\begin{array}{c}\text { Fat } \\
(\mathrm{g} / 100 \mathrm{~mL})\end{array}$ & $\begin{array}{c}\text { Protein } \\
(\mathrm{g} / 100 \mathrm{~mL})\end{array}$ & $\begin{array}{c}\text { Lactose } \\
(\mathrm{g} / 100 \mathrm{~mL})\end{array}$ & $\begin{array}{c}\mathrm{SNF} \\
(\mathrm{g} / 100 \mathrm{~mL})\end{array}$ & $\mathrm{pH}$ \\
\hline Lacaune & CONT & $8.13 \pm 0.57$ & $5.90 \pm 0.24$ & $4.13 \pm 0.18$ & $10.94 \pm 0.28^{\mathrm{d}}$ & $7.00 \pm 0.04^{\mathrm{a}}$ \\
\hline Campaniça & NCT & $11.68 \pm 1.22$ & $5.15 \pm 0.50$ & $4.73 \pm 0.38$ & $10.83 \pm 0.59^{\mathrm{d}}$ & $6.54 \pm 0.09^{\mathrm{c}}$ \\
\hline \multirow[t]{2}{*}{ Merino } & CONT & $10.07 \pm 0.54$ & $7.24 \pm 0.22$ & $4.54 \pm 0.17$ & $12.67 \pm 0.27^{\mathrm{ab}}$ & $6.81 \pm 0.04^{\mathrm{b}}$ \\
\hline & NCT & $9.78 \pm 0.77$ & $7.74 \pm 0.32$ & $4.64 \pm 0.24$ & $13.10 \pm 0.38^{\mathrm{a}}$ & $6.72 \pm 0.06^{b c}$ \\
\hline
\end{tabular}

${ }^{\mathrm{a}-\mathrm{d}}$ Means within a column with different superscripts differ $(P<0.05)$.

${ }^{1}$ Contamination status: $\mathrm{CONT}=$ contaminated; $\mathrm{NCT}=$ noncontaminated.

Our results highlight the high sensitivity of molecular techniques, based on amplification of small quantities of DNA, which allows detection of contaminated animals in the early stages of the inflammatory process. Moreover, our results demonstrate that molecular screening methodologies can detect contaminated raw milk samples that would be considered normal by other parameters (such as milk chemical composition and SCC). The same samples may already contain some pathogenic agents, as demonstrated by molecular results, which ultimately might be responsible for an early inflammation process in the mammary gland, which can later evolve to mastitis.

To the best of our knowledge, this was the first study to report use of a molecular diagnostic tool to identify ovine subclinical mastitis in 3 breeds of sheep raised in Portugal. Based on the observed results, $54 \%$ of all milk samples analyzed, from all breeds studied, were contaminated with one or more mastitis-causing pathogens. This percentage is significantly higher than others found in literature for the prevalence of ovine subclinical mastitis (Al-Majali and Jawabreh, 2003; Bergonier et al., 2003), probably because of the higher sensitivity and accuracy of molecular biology-based techniques. The results highlight the advantage of this molecular screening method, which is an affordable process for ovine mastitis screening that allows a faster and efficient identification of contaminated raw sheep milk, which may ultimately lead to more specific and efficient animal treatment and, consequently, less expensive flock management.

\section{CONCLUSIONS}

The development of mastitis control programs in milk-producing dairy sheep flocks depends on market requirements, especially within the cheese-making industry, which until now has not set a regulatory standard for raw milk chemical composition in some countries, including Portugal. Development of highly sensitive techniques for ovine mastitis detection, com- bined with procedures to standardize milk composition and SCC, form the basis of new strategies to improve raw sheep milk quality.

\section{ACKNOWLEDGMENTS}

We acknowledge all the ovine producers from the Baixo Alentejo region of Portugal who kindly participated by donating raw milk samples, as well as Herdade da Abóbada (Serpa, Portugal) and the Associação de Criadores de Ovinos do Sul (ACOS, Beja, Portugal). This work was partially supported by FCT research grants from Zélia Velez: SFRH/BPD/63417/2009. The CICECO (Aveiro, Portugal), an Associated Laboratory from Portuguese Ministry of Science is financed by Pest-C/CTM/LA0011/2011.

\section{REFERENCES}

Abilleira, E., M. Virto, A. I. Najera, J. Salmeron, M. Albisu, F. J. Perez-Elortondo, J. C. R. de Gordoa, M. de Renobales, and L. J. R. Barron. 2010. Effects of seasonal changes in feeding management under part-time grazing on the evolution of the composition and coagulation properties of raw milk from ewes. J. Dairy Sci. 93:3902-3909.

Al-Majali, A. M., and S. Jawabreh. 2003. Period prevalence and etiology of subclinical mastitis in Awassi sheep in Southern Jordan. Small Rumin. Res. 47:243-248.

Albenzio, M., M. Caroprese, A. Santillo, R. Marino, L. Taibi, and A. Sevi. 2004. Effects of somatic cell count and stage of lactation on the plasmin activity and cheese-making properties of ewe milk. J. Dairy Sci. 87:533-542.

Alvarenga, N., P. Silva, J. R. Garcia, and I. Sousa. 2008. Estimation of Serpa cheese ripening time using multiple linear regression (MLR) considering rheological, physical and chemical data. J. Dairy Res. 75:233-239.

Barillet, F., R. Rupp, S. Mignon-Grasteau, J. M. Astruc, and M. Jacquin. 2001. Genetic analysis for mastitis resistance and milk somatic cell score in French Lacaune dairy sheep. Genet. Sel. Evol. 33:397-415.

Bentley, R. W., and J. A. Leigh. 1995. Determination of 16S ribosomal RNA gene copy number in Streptococcus uberis, S. agalactiae, $S$. dysgalactiae and $S$. parauberis. FEMS Immunol. Med. Microbiol. $12: 1-7$.

Bergonier, D., R. de Cremoux, R. Rupp, G. Lagriffoul, and X. Berthelot. 2003. Mastitis of dairy small ruminants. Vet. Res. 34:689-716.

Berri, M., K. Laroucau, and A. Rodolakis. 2000. The detection of Coxiella burnetii from ovine genital swabs, milk and fecal samples 
by the use of a single touchdown polymerase chain reaction. Vet. Microbiol. 72:285-293.

Bianchi, L., A. Bolla, E. Budelli, A. Caroli, C. Casoli, M. Pauselli, and E. Duranti. 2004. Effect of udder health status and lactation phase on the characteristics of Sardinian ewe milk. J. Dairy Sci. $87: 2401-2408$.

Bradley, A. 2002. Bovine mastitis: An evolving disease. Vet. J. 164:116-128.

Cremonesi, P., B. Castiglioni, G. Malferrari, I. Biunno, C. Vimercati, P. Moroni, S. Morandi, and M. Luzzana. 2006. Technical note: Improved method for rapid DNA extraction of mastitis pathogens directly from milk. J. Dairy Sci. 89:163-169.

Cuccuru, C., M. Meloni, E. Sala, L. Scaccabarozzi, C. Locatelli, P. Moroni, and V. Bronzo. 2011. Effects of intramammary infections on somatic cell score and milk yield in Sarda sheep. N. Z. Vet. J. $59: 128-131$.

Dotti, I. B. S. 2011. Integrity assessment of nucleic acids. Pages 81-85 in Guidelines for Molecular Analysis in Archive Tissues. G. Stanta, ed. Springer, Trieste, Italy.

Lafi, S. Q., A. M. Al-Majali, M. D. Roussan, and J. M. Alawneh. 1998. Epidemiological studies of clinical and subclinical ovine mastitis on Awassi sheep in northern Jordan. Prev. Vet. Med. 33:171-181.

Leitner, G., U. Merin, and N. Silanikove. 2004. Changes in milk composition as affected by subclinical mastitis in goats. J. Dairy Sci. $87: 1719-1726$.

Leitner, G., U. Merin, and N. Silanikove. 2011. Effects of glandular bacterial infection and stage of lactation on milk clotting parameters: Comparison among cows, goats and sheep. Int. Dairy J. $21: 279-285$.

Lipkin, E., A. Shalom, H. Khatib, M. Soller, and A. Friedmann. 1993. Milk as a source of deoxyribonucleic acid and as a substrate for the polymerase chain reaction. J. Dairy Sci. 76:2025-2032.

López-Calleja, I., I. Gonzalez, V. Fajardo, M. A. Rodriguez, P. E. Hernandez, T. Garcia, and R. Martin. 2004. Rapid detection of cows' milk in sheeps' and goats' milk by a species-specific polymerase chain reaction technique. J. Dairy Sci. 87:2839-2845.

Mafra, I., I. M. Ferreira, M. A. Faria, and B. P. Oliveira. 2004. A novel approach to the quantification of bovine milk in ovine cheeses using a duplex polymerase chain reaction method. J. Agric. Food Chem. 52:4943-4947.

McDonald, W. L., B. N. Fry, and M. A. Deighton. 2005. Identification of Streptococcus spp. causing bovine mastitis by PCR-RFLP of 16S-23S ribosomal DNA. Vet. Microbiol. 111:241-246.
Meiri-Bendek, I., E. Lipkin, A. Friedmann, G. Leitner, A. Saran, S. Friedman, and Y. Kashi. 2002. A PCR-based method for the detection of Streptococcus agalactiae in milk. J. Dairy Sci. 85:17171723.

Miller, S. A., D. D. Dykes, and H. F. Polesky. 1988. A simple salting out procedure for extracting DNA from human nucleated cells. Nucleic Acids Res. 16:1215.

Mørk, T., S. Waage, T. Tollersrud, B. Kvitle, and S. Sviland. 2007. Clinical mastitis in ewes; bacteriology, epidemiology and clinical features. Acta Vet. Scand. 49:23.

Murphy, M. A., M. R. Shariflou, and C. Moran. 2002. High quality genomic DNA extraction from large milk samples. J. Dairy Res. 69:645-649.

National Mastitis Council. 1998. Current Concepts of Bovine Mastitis. 4th ed. Natl. Mastitis Council, Madison, WI

Ogola, H., A. Shitandi, and J. Nanua. 2007. Effect of mastitis on raw milk compositional quality. J. Vet. Sci. 8:237-242.

Raynal-Ljutovac, K., A. Pirisi, R. De Cremoux, and C. Gonzalo. 2007. Somatic cells of goat and sheep milk: Analytic, sanitary, productive and technological aspects. Small Rumin. Res. 68:126-144.

Reale, S., A. Campanella, A. Merigioli, and F. Pilla. 2008. A novel method for species identification in milk and milk-based products. J. Dairy Res. 75:107-112.

Riffon, R., K. Sayasith, H. Khalil, P. Dubreuil, M. Drolet, and J. Lagace. 2001. Development of a rapid and sensitive test for identification of major pathogens in bovine mastitis by PCR. J. Clin. Microbiol. 39:2584-2589.

Santos, J., P. Fernandes, and R. Bardsley. 2003. Portuguese "PDO" cheese and species origin of milk. J. Environ. Agric. Food Chem. $2: 476-479$

Sevi, A., M. Albenzio, R. Marino, A. Santillo, and A. Muscio. 2004. Effects of lambing season and stage of lactation on ewe milk quality. Small Rumin. Res. 51:251-259.

Sevi, A., L. Taibi, M. Albenzio, G. Annicchiarico, and A. Muscio. 2001. Airspace effects on the yield and quality of ewe milk. J Dairy Sci. 84:2632-2640.

Viguier, C., S. Arora, N. Gilmartin, K. Welbeck, and R. O'Kennedy. 2009. Mastitis detection: Current trends and future perspectives. Trends Biotechnol. 27:486-493. 